\title{
First report of an invasive pest, Phyllonorycter populifoliella (Lepidop- tera: Gracillariidae) from Ladakh
}

\author{
Barkat HUSSAIN ${ }^{1,2}$, Abdul Rasheed WAR ${ }^{3}$, Ajaz Ahmad KANDOO ${ }^{1}$
}

Received August 21, 2020; accepted May 24, 2021.

Delo je prispelo 21. avgusta 2020, sprejeto 24. maja 2021

\begin{abstract}
First report of an invasive pest, Phyllonorycter populifoliella (Lepidoptera: Gracillariidae) from Ladakh

Abstract: Phyllonorycter populifoliella (Treitschke 1883), is an invasive pest and is first reported on poplar trees, from the eastern region of Ladakh, India. The details of the taxonomic identification based on genital morphology are presented. Besides, host range, feeding habits and level of infestation in different hamlets of Ladakh are also presented. This study is important for further understanding the pest biology, its diversity and management by adopting control strategies. It is also important to restrict its dispersal to other states of the Indian union and to devise pest management strategies for this pest.
\end{abstract}

Key words: Ladakh; Phyllonorycter populifoliella; poplar; invasive pest
Prvo poročilo o invazivnem škodljivcu na topolu, listnem zavrtaču Phyllonorycter populifoliella (Lepidoptera: Gracillariidae), na območju Ladakha

Izvleček: Listni zavrtač Phyllonorycter populifoliella (Treitschke 1883) je invazivna vrsta, o kateri prvič poročamo o pojavljanju na topolih v Ladakhu, Indija. Predstavljene so podrobnosti taksonomske določitve škodljivca na podlagi zunanje zgradbe genitalij. Poleg tega so predstavljeni še spekter njegovih gostiteljskih rastlin, habitati, v katerih se prehranjuje in stopnja napadenosti rastlin $\mathrm{s}$ tem škodljivcem $\mathrm{v}$ različnih zaselkih Ladakha. Raziskava je zelo pomembna za boljše razumevanje bionomije škodljivca, njegove diverzitete in odločanju o strategijah njegovega zatiranja. Pomembna je tudi za omejevanje njegovega širjenja na druga območja Indije in pri snovanju strategij za zatiranje tega škodljivca.

Ključne besede: Ladakh; Phyllonorycter populifoliella; topol; invazivni škodljivec

1 Division of Entomology, SKUAST-K, Shalimar-190025, Srinagar, Jammu and Kashmir, India

2 Corresponding author, e-mail: bhatbari@rediffmail.com

3 Natco Crop Health Sciences, Jubilee Hills-5000034, Telangana, India 


\section{INTRODUCTION}

Ladakh is a cold desert region that spans over $70,000 \mathrm{~km}^{2}$. This is India's high altitude, cold arid zone, which has harsh climatic conditions. This area, however, is endowed with unique flora and fauna, with poplars and willows serving as the main timber trees of the silviculture-agroforestry system. The poplar species in Ladakh include Populus euphractica Oliv., P. alba L., P. nigra L., P. ciliata Wall. ex Royle and P. balsamifera L. belonging to order Malpighiales and family Salicaceae. Poplar trees are used for wood as raw material for manufacturing furniture, doors, windows and other decorative objects. Additionally, these trees help to prevent soil erosion (Naithani \& Nautiyal, 2012). Poplar trees meet the increased demand for fuelwood during harsh winters when temperatures drop below $-30{ }^{\circ} \mathrm{C}$ (Kumar \& Singh, 2012).

Several insect pests attack poplars around the world. Among them are defoliating beetle, Chrysomela populi (Lin., 1767) (Coleoptera: Chrysomelidae), tent caterpillar, Malacosoma indica Walker, 1855 (Lepidoptera: Lasiocampidae), Indian gypsy moth, Lymantria abfuscata Walker, 1865 (Lepidoptera: Erebidae) and poplar petiole gall aphid, Pemphigus spp. Passerini (Hemiptera: Aphididae) are some of the most common insect pests of poplar trees in Ladakh (Kumar et al., 2007). The poplar leaf blotch miner Phyllonorycter populifoliella (Treitschke, 1883) (Lepidoptera: Gracillariidae) has recently emerged as a threat to poplar plantations in this region (REF). Graccillariidae is a large family of leaf-mining insects that includes 107 recognised genera and 1993 species that feed on 7868 host plants (Anonymous, 2019). The majority of species can be found in temperate climates; 257 species have been described from the Palaearctic region and 81 from Neoarctic (De Prins \& De Prins, 2009). The larvae breed in the leaf mesophyll (Davis \& Robinson, 1998) and were first discovered in 1989 near the Kharkiv region of Ukraine (Sulkhanov, 1990).

In Graccillariidae family, larval development occurs up to four stages (Trägardh, 1913), known as hypermetamorphosis or heteromorphic development (Wagner et al., 2000). The initial larval stages feed on tree sap, while the later stages feed on tissues. The later larval stages contain well-developed chewing mandibles and hypognathous mouthparts and are called tissue feeding forms (Trägardh, 1913).

\subsection{BIOLOGY OF PHYLLONORYCTER spp.}

They are small insects and disperse rapidly from one locality to another in Ladakh, since there are no strict quarantine regulations around borders with China and Pakistan. The genus Phyllonorycter comprises over 380 species from all the zoogeographical regions (De Prins \& De Prins, 2005). They have been found on 112 different plant genera in 31 different families (Lopez-Vaamonde et al., 2003; De Prins \& De Prins, 2009). The larvae of Phyllonorycter spp. feed internally on living tissues of the plant and devour the parenchyma cells. The pupa and all pre-imaginal stages of the Phyllonorycter genus grow within a tentiform mine (Davis \& Robinson, 1998). The larvae live inside the galleries, which provide them with shelter during adverse climatic conditions and protects them from natural enemies (Connar \& Taverner, 1997).

During favourable conditions, moths are multivoltine and insect outbreaks occur on native plants (Bengtsson \& Johansson, 2011; De Prins \& Kawahara, 2012). The successive generations cause significant damage to woody plants (Kirichenko et al., 2019). The adult's small size allows them to pass through small crevices and holes in windowpanes or can be seen glued on the door entrances. The early larval instars invade all types of poplars and mine the leaves of the hosts. They make tentiform mines on the lower surface of the leaves. Generally, larvae grow on the underside of leaf and occasionally feed and make mines on the upper side of the leaf (Mutanen et al., 2007).

Our study reports the presence of this pest and infestation for the first time from Ladakh, India. The genital morphology of P. populifoliella was used to determine its taxonomic status. There has been no previous report on the possible presence of this pest in Ladakh, India.

\section{MATERIALS AND METHODS}

The study was conducted in Ladakh, India. Poplar is one of the important sources of timber in this region. There are about 10 species of poplars grown at different altitudes, including Populus euphratica, $P$. alba, $P$ ciliata etc. The main surveyed areas in this study included Khaltsi, Phyang, Basgo, Stakna, Saspol, Minji, Silichee, Karbuthang and Hardas (Figure 1). Surveys were carried out in June and August 2018. Every three weeks, the poplar trees were selected randomly from the selected locations to observe the leaf miner damage on newly flushed leaves. Twenty shoots were observed from the lower canopy $(1.0 \mathrm{~m})$, at random from 50 trees per location and the number of leaves per shoots per tree was counted to calculate per cent infestation acord- 


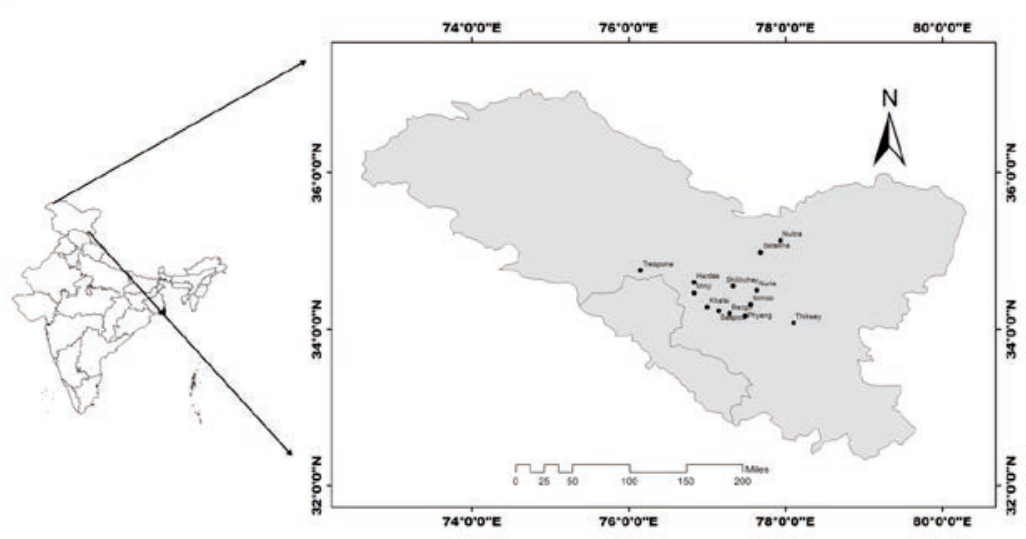

Figure 1: Survey locations for the survey of Phyllonorycter populifoliella on poplar trees in Ladakh, India

ing to Peña et al. (2000). The larvae were collected from the infested leaves and reared in plastic containers. The adults emerging were recorded on daily basis.

The data on infestation was subjected to analysis of variance (ANOVA) and Duncan's Multiple Range Test (DMRT) to understand the significant difference across different locations (SPSS (v.15.1; SPSS 168 Inc., Chicago, IL).

The infested leaves were excised and brought to High Altitude Entomology Laboratory at Satakna, Leh, Ladakh, and then kept in polystyrene jars glued with nylon lids on the top. The infested leaves were maintained at ambient temperature and periodically inspected for adult emergence for taxonomic identification. To study the morphology of genitalia, the methodology of Robinson (1976) was followed with slight modifications. The abdomens were cut and macerated in $10 \% \mathrm{KOH}$ solution for 18 hours to dissolve the extra body tissues. The samples were processed in $80 \%$ ethanol. The genitalia were observed under a stereoscope binocular microscope (Olympus 598472, Japan).

\section{RESULTS AND DISCUSSION}

\subsection{TAXONOMY}

Poplar leaf blotch miner, p populifoliella (Treitschke, 1883), has been regarded as one of the most important pests globally (Selikhovkin, 2010). The species of the genus Phyllonorycter are difficult to identify because of the small size of adults and their wing pattern is rather similar across the species. In the middle Volga area of Russia, 13 species of the genus Phyllonorycter were identified based on female genitalia (Mishchenko, 2014). The descriptions of female genita lia were in accordance with Kuznetsov (1981). Noreika (1997) published the diagnostic keys of some species of this genus based on the structure of male genitalia. Rumyantsev (1934) confirmed the specimens of leaf miner in St. Petersburg as P. populifoliella based on genital morphology. The adults of $P$. populifoliella are relatively small (wingspan 6-9 $\mathrm{mm}$ ). The forewings are white in colour with brown and ochre chess designs. The hind wings are white and translucent. Both front and hind wings are heavily fringed. The head is covered with a large tuft of white-colored hairs (Figure 2). The larvae pass through five instars and pupation takes place in the mines of the infested leaves. The entire development (from egg to adult) takes about 10-14 days. The larvae feed on poplar leaves, mining the bottom surface of leaves to form a tentiform mine without a fold (Figure 3). Pupation takes place in a rounded cocoon within a mine in the infested leaves. The second generation occurs in the second half of July. The pupa of the second generation undergoes diapause. High rates of infestations were observed in the study areas. The lowest infestation of $30 \%$ was recorded in Nurla village, while the maximum infestation of $55.50 \%$ recorded in the Nubra valley of Ladakh (Table 1).

Taxonomic keys to some species of the genus Phyllonorycter:

1 Presence of asymmetrical basal process of sacculus with a straight spine------2

- Absence of asymmetrical basal process of sacculus-------------------------3

2 Cucullus provided with short dense hairs, corpus bursae with not well developed signum -Phyllonorycter mespilella.

- Cucullus not provided with dense hairs. Valve long and narrow, sharp apical valval spines -Phyllonorycter trifasciella. 
3 Spines not present on apical parts of valve. Valve wide, slightly asymmetrical with small projection on right cucullus, corpus bursae with well-developed signum------------Phyllonorycter populifoliella.

Table 1: Infestation (\% per branch of lower area) by Phyllonorycter populifoliella on poplar trees at different locations in Ladakh, Indiations in Ladakh, India

\begin{tabular}{ll}
\hline Location & Infestation $(\%)$ \\
\hline Mathoo & $30.50 \pm 2.9^{\mathrm{fg}}$ \\
Satakna & $45.25 \pm 4.2^{\mathrm{d}}$ \\
Tikhsey & $42.35 \pm 2.5^{\mathrm{d}}$ \\
Chachoot & $50.00 \pm 3.9^{\mathrm{c}}$ \\
Nubra & $55.50 \pm 5.5^{\mathrm{b}}$ \\
Goma & $44.35 \pm 5.0^{\mathrm{d}}$ \\
Bazgo & $34.54 \pm 3.5^{\mathrm{f}}$ \\
Nurla & $30.00 \pm 2.8^{\mathrm{f}}$ \\
Saspool & $50.50 \pm 6.0^{\mathrm{a}}$ \\
Nimoo & $35.00 \pm 2.8^{\mathrm{f}}$ \\
Khalsi & $42.50 \pm 6.2^{\mathrm{d}}$ \\
Phyang & $40.20 \pm 3.9^{\mathrm{de}}$ \\
Minji & $32.00 \pm 2.6^{\mathrm{f}}$ \\
Shilichee & $28.80 \pm 3.0^{\mathrm{g}}$ \\
Hardas & $35.50 \pm 4.1^{\mathrm{f}}$ \\
Trespone & $47.25 \pm 5.0^{\mathrm{d}}$ \\
Leh city & $60.50 \pm 5.8^{\mathrm{a}}$ \\
\hline
\end{tabular}

Values (Mean \pm SE) with similar letters within a row do not differ significantly at $\mathrm{p} \leq 0.05$ (DMRT)

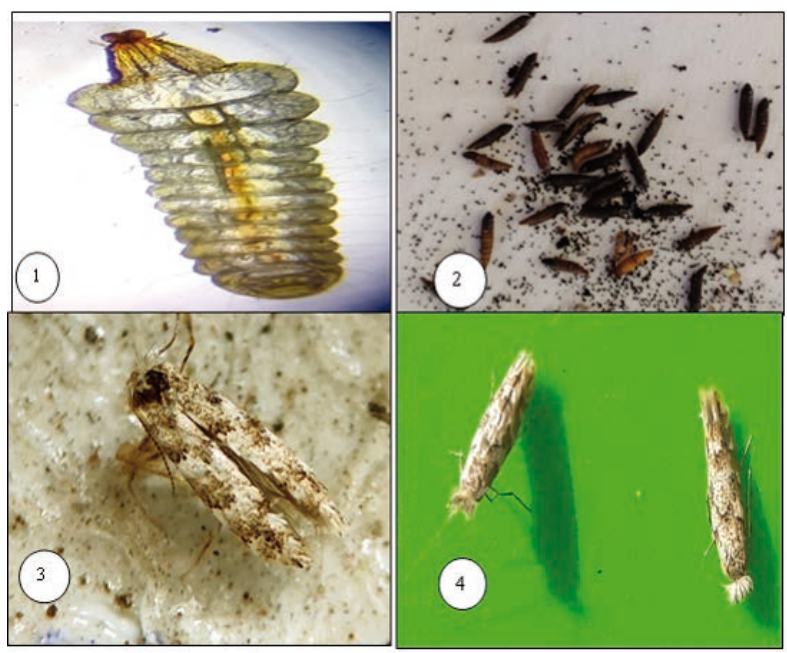

Figure 2: Life stages of Phyllonorycter populifoliella: 1. Larva, 2. Pupae, 3 and 4. Adults (Female-left, Male-right)

\subsection{MALE AND FEMALE GENITALIA OF PHYL- LONORYCTER POPULIFOLIELLA}

Male genitalia with tegument is heavily sclerotized, half ring-shaped; juxta not clearly visible; valvae are wide and slightly asymmetrical with a small projection on left valva; sacculus is narrow and cucullus is wide with short and thin hairs on inner side; aedeagus is long, narrow, cylindrical-shaped with its basal end round and swollen (Figure 4).

Female genitalia has spherical corpus bursae, signum is spherical having two teeth; ostium bursae are without sclerotisation; anterior apophyses are longer than the posterior apophyses; papilla analis is trapezoidal, setose; ductus bursae are delicate, more or less zig-zag in shape with sac-like structure hanging on one side. The anterior and posterior margins of abdominal segment VII are not sclerotised (Figure 4).

\subsection{LOCALITIES OF SPECIMENS EXAMINED}

India: Ladakh, District Kargil and Leh; Minji, $34^{\circ} 28^{\prime} \mathrm{N}$ and $76^{\circ} 50^{\prime} \mathrm{E}$; Shilichee $34^{\circ} 33^{\prime} \mathrm{N}$ and $76^{\circ} 80^{\prime}$ E; Hardas $34^{\circ} 36^{\prime} \mathrm{N}$ and $76^{\circ} 50^{\prime} \mathrm{E}$. Trespone $34^{\circ} 45^{\prime} \mathrm{N}$ and $76^{\circ} 09^{\prime} \mathrm{E}$; Bazgo $34^{\circ} 12^{\prime} \mathrm{N}$ and $76^{\circ} 80^{\prime} \mathrm{E}$; Phyang $34^{\circ} 10^{\prime} \mathrm{N}$ and $77^{\circ} 29^{\prime} \mathrm{E}$; Satakna $33^{\circ} 59^{\prime} \mathrm{N}$ and $77^{\circ} 41^{\prime} \mathrm{E}$; Khalsi $34^{\circ} 17^{\prime} \mathrm{N}$ and $77^{\circ} 0^{\prime} \mathrm{E}$; Nubra $34^{\circ} 68^{\prime} \mathrm{N}$ and $77^{\circ} 56^{\prime}$ E; Nurla $34^{\circ} 30^{\prime} \mathrm{N}$ and $76^{\circ} 98^{\prime} \mathrm{E}$; Thiksey $34^{\circ} 05^{\prime} \mathrm{N}$ and $77^{\circ} 66^{\prime} \mathrm{E}$; Nimoo $34^{\circ} 19^{\prime} \mathrm{N}$ and $77^{\circ} 33^{\prime} \mathrm{E}$; Saspool $34^{\circ} 14^{\prime}$ $\mathrm{N}$ and $77^{\circ} 9^{\prime} \mathrm{E}$.

\subsection{INFESTATION}

The P. populifoliella was recorded across the tested regions. The lower surfaces of the leaves and leaves of the lower branches were highly infested (Figure 3).

\subsection{HOST RANGE}

The main hosts of Phyllonorycter populifoliella, include black poplars such as Populus nigra, balsam poplars, such as P. balsamifera, P. suaveolens Fisch. ex Poit. \& A.Vilm. and P. laurifolia Ledeb. (Ellis 2020; Ermolaev et al. 2020). The species of poplars in this study could not be identified due to the presence of several exotic hybrids in Ladakh. 


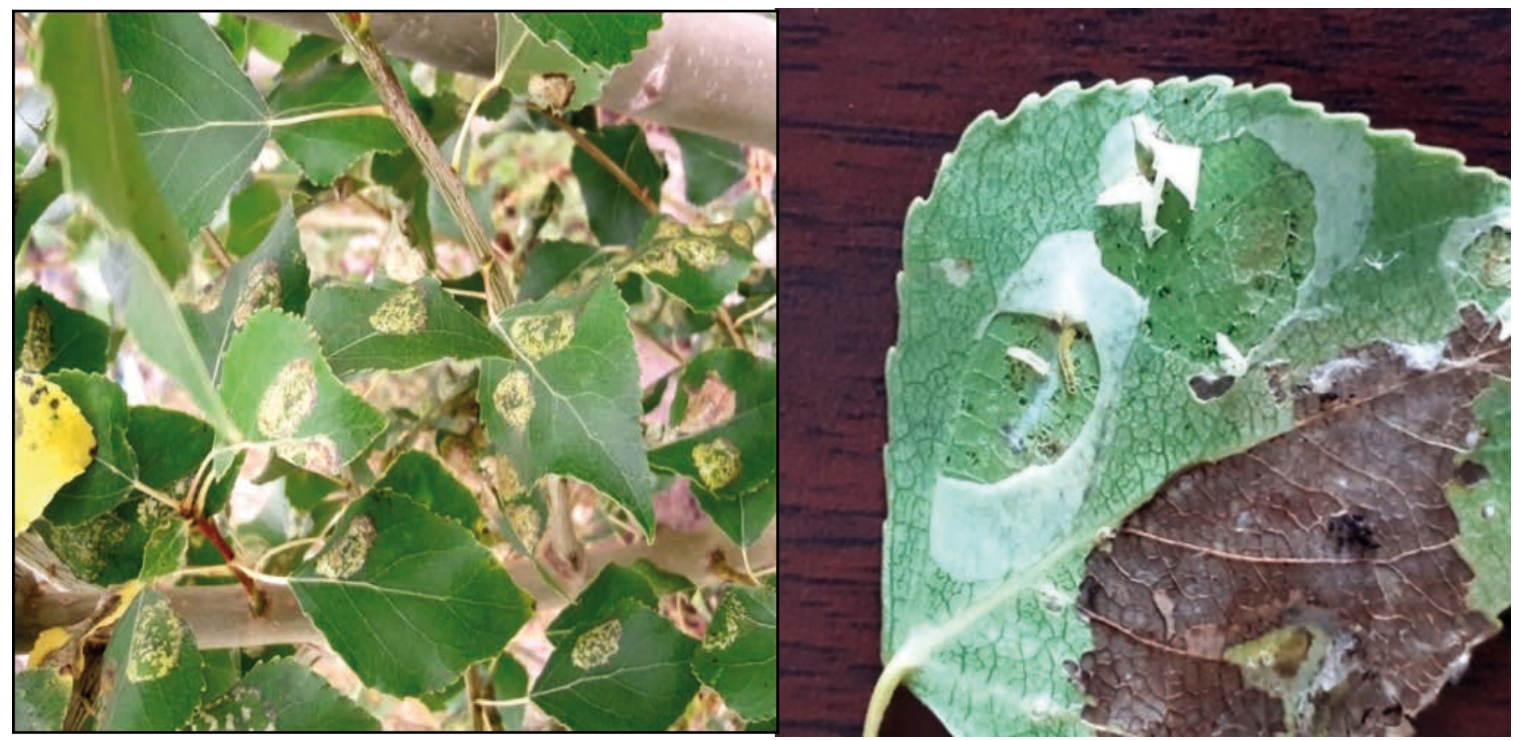

Figure 3: Damage symptoms of Phyllonorycter populifoliella infestation on poplar leaves
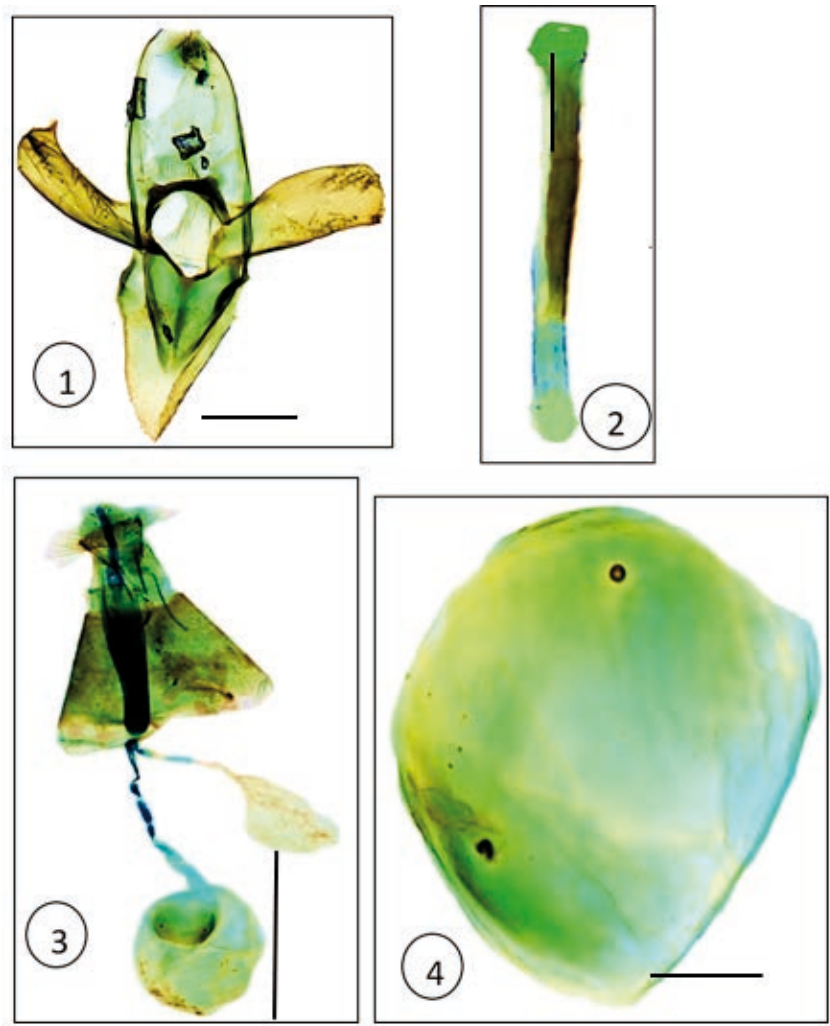

Figure 4: Genital morphology of Phyllonorycter populifoliella: 1. Male genitalia; 2. Aedeagus: 3. Female genitalia; 4. Signum. Scale bars: 1-2 (200 $\mu \mathrm{m}), 3(500 \mu \mathrm{m}), 4(300 \mu \mathrm{m})$ 


\subsection{DISTRIBUTION}

Austria, Belgium, Denmark, France, Germany, Italy, Russia, Spain, Turkey, Ukraine, United Kingdom.

\subsection{DAMAGE}

Though the leaf miner infestation does not cause immediate defoliation, reduced photosynthetic leads to reduced tree growth. Further, defoliation levels depend on the season and age and type of infested host (Raimondo et al., 2003), and summer defoliation has a strong impact on tree growth (Raimondo et al., 2003). Repeated defoliation over consecutive years can kill the trees. In addition, defoliation induced by leaf miners diminishes the aesthetic value of poplars.

\section{CONCLUSION}

This is for the first time that the poplar leaf miner P. populifoliella has been reported in the region of Ladakh, India. Though the pest could have been in the region much earlier, research was not conducted on this pest. In Ladakh, there are four native poplar species and many exotic poplars (Naithani \& Nautiyal 2012). The presence of $P$. populifoliella in Ladakh can be attributed to the diversity of native and exotic species of poplars in this region, which are the main hosts of this insect. Till now, this pest has remained undiscovered due to the less density of poplars. Since poplars are the major source of firewood in the region, the discovery of new insect pests puts a major challenge to this industry. Further, in-depth studies on biology, pest behaviour and management strategies need to be worked out to contain this pest.

\section{REFERENCES}

Anonymous. (2019). Global taxonomic database of Gracilleridae. www.Gracilleridae.net (Assessed on July 04, 2020)

Bengtsson B.A., Johansson, R. (2011). Fjärilar: Bronsmalar - rullvingemalar. Lepidoptera: Roeslerstammiidae -Lyonetiidae. ArtDatabanken, Sveriges lantbruksuniversitet, Uppsala, pp. 494.

Connor E.F., Taverner M.P. (1997). The evolution and adaptive significance of the leaf-mining habit. Oikos, 79, 6-25. https://doi.org/10.2307/3546085

Davis D.R., Robinson G.S. (1998). The Tineoidea and Gracillarioidea. In: Kristensen, N.P. editor. Handbook of Zoology IV/35, Lepidoptera, Moths and Butterflies.
Vol. 1. Evolution, Systematics, and Biogeography. Walter de Gruyter, Berlin, New York, pp. 91-117. https://doi. org/10.1515/9783110804744.91

De Prins J., Kawahara A. (2012). Systematics, revisionary taxonomy, and biodiversity of Afrotropical Lithocolletinae (Lepidoptera: Gracillariidae). Zootaxa, 3594, 1-283. https://doi.org/10.11646/zootaxa.3594.1.1

De Prins J., De Prins W. (2009). Global Taxonomic Database of Gracillariidae (Lepidoptera). Royal Museum for Central Africa, Belgian Biodiversity Platform, Tervuren, Brussels, Belgium. Available from http://gc.bebif.be. (Assessed on July 10, 2020)

De Prins W., De Prins J. (2005). Gracillariidae, In World Catalog of Insects Apollo Books, Stenstrup, vol. 6.

Kirichenko N, Augustin S., Kenis, M. (2019). Invasive leaf miners on woody plants: a global review of pathways, impact, and management. Journal of Pest Science, 92, 93-106. https://doi.org/10.1007/s10340-018-1009-6

Kumar P.A., Namgyal D., Mir M.S., Bilal, A.S. (2007). Major insect pest associated with forest plantations in cold arid region, Ladakh of Jammu and Kashmir. Journal of Entomological Research, 31(2), 155-162.

Kumar D., Singh, N.B. (2012). Status of poplar introduction in India. ENVIS Forestry Bulletin, 12, 9-14.

Kuznetsov V.I. (1981). Family Gracillariidae Leaf Blotch Miners," In: Medvedev, G.S. editor. A Key to the Insects of the European Part of the USSR, (Nauka, Leningrad,), vol. IV, part 2,149-311.

Lopez-Vaamonde C., Godfray H.C.J., Cook J.M. (2003). Evolutionary dynamics of hostplant use in a genus of leaf mining moths. Evolution, 57, 1804-1821. https://doi. org/10.1111/j.0014-3820.2003.tb00588.x

Mishchenko A.V. (2014). A Review of the Leaf Blotch Miners of the Genus Phyllonorycter Hübn. (Lepidoptera, Gracillariidae) in the Middle Volga Area, with a Key to the Species Using morphological Characters of the Female Genitalia. Entomological Review, 94(9), 1342-1347. https://doi. org/10.1134/S0013873814090176

Mutanen M., Itämies J., Kaila, L. (2007). Heliozela resplendella (Stainton, 1851) and H. hammoniella Sorhagen, 1885: two valid species distinguishable in the genitalia of both sexes and life histories (Heliozelidae). Nota Lepidopterologica, 30(1), 79-92.

Naithani H.B., Nautiyal S. (2012). Indian Poplars with special reference to indigenous species. Forestry Bulletin, 12(1), 1-8

Noreika R.V. (1997). Family Gracillariidae-Leaf Blotch Miners, In: Lehr, P.A. editor. A Key to the Insects of the Russian Far East, (Dal'nauka, Vladivostok,), 5(1), 373-429.

Peña J.E., Hunsberger A., Schaffer, B. (2000). Citrus leafminer (Lepidoptera: Gracillariidae) density: Effect on yield of 'Tahiti' lime. Journal of Economic Entomology, 93, 374-379. https://doi.org/10.1603/0022-0493-93.2.374

Raimondo F., Ghirardelli L.A., Nardini A., Salleo, S. (2003). Impact of the leaf miner Cameraria ohridella on photosynthesis, water relations and hydraulics of Aesculus hippocastanum leaves. Trees - Structure and Function, 17, 376-382. https://doi.org/10.1007/s00468-003-0248-0 
Robinson G.S. (1976). The preparation of slides of Lepidoptera genitalia with special reference to the Microlepidoptera. Entomologist's Gazette, 27, 127-132.

Rumyantsev P.D. (1934). Biology of the Poplar Leaf Blotch Miner (Lithocolletis populifoliella Tr.) in Moscow, Zoologicheskii Zhurnal, 12(2), 257-279.

Selikhovkin A.V. (2010). Specific features of popu-lation dynamics of the poplar leaf blotch miner Phyllonorycter populifoliella Tr. (Gracillariidae)," Izvestiya Sankt-Peterburgskoi sotekhnicheskoi Akademii, 192, 220-235.

Sulkhanov A.V. (1990). Species composition and spatial distribution of parasites of the poplar moth Lithocolletis populifoliella Tr.. Biologicheskie Nauki 7, 33-40.

Trägardh I. (1913). Contributions towards the comparative morphology of the trophi of the lepidopterous leaf-miners. Arkiv för Zoologi, 8, 148. 